\title{
Possible Hybridization of Brazilian Planorbid Snails and its Importance in Population Dynamics
}

\author{
Clélia Christina Mello-Silva, Carlos Eduardo Grault/ ${ }^{+}$, Valdir Almeida da \\ Costa*, Frederico Simões Barbosa**
}

Departamento de Ciências Biológicas, Escola Nacional de Saúde Pública, Fiocruz, Rua Leopoldo Bulhões 1480 , 21041-210 Rio de Janeiro, RJ, Brasil *Fundação Nacional de Saúde, Rio de Janeiro, RJ, Brasil **Centro de Pesquisas Aggeu Magalhães-Fiocruz, Recife, PE, Brasil

This study focuses on the possibility of experimental hybridization among host snail species for Schistosoma mansoni in Brazil, with morphological characterization of the hybrids found. By using albinism as a genetic marker, intraspecific crossbreedings were performed between two strains of each species involved, in addition to interspecific crossbreedings; the only viable crossbreeding was between pigmented Biomphalaria glabrata (Paulista, PE) and albino B. tenagophila (Joinville, SC), with the formation of $F 1$ and $F 2$ generations.

All offspring in $F 1$ displayed black eyes and a renal ridge on the mantle, while F2 displayed dissociated morphological traits. With regard to reproduction, $F 1$ was more efficient than $F 2$. The experiment's results suggest post-zygotic reproductive isolation.

Key words: schistosomiasis - Biomphalaria - hybridization

Schistosomiasis mansoni is one of the most ecologically relevant endemic diseases. Part of the parasite's life cycle occurs in bodies of fresh water, where one finds mollusks of the Biomphalaria genus, intermediate hosts for this parasitosis in Brazil. To date, three species have proven to be epidemiologically relevant: $B$. glabrata, $B$. tenagophila, and $B$. straminea.

Intraspecific and interspecific crossbreedings among host species have been described in the literature since the 1950s. Paraense (1955) and Paraense and Deslandes (1955) performed experiments based on intra- and interspecific crossbreeding. The former, intraspecific crossbreeding, aimed to establish these species' reproductive preferences, while the latter focused on the possibility of interspecific crossbreeding between B. glabrata and $B$. tenagophila, which were located $315 \mathrm{~km}$ from each other. The authors observed in these respective experiments that cross-fecundation is preferential and that the crossbreeding proposed was not viable, reporting reproductive isolation between the species of Biomphalaria studied.

\footnotetext{
This work was supported by CNPq.

${ }^{+}$Corresponding author. Fax: +55-21-564.8985. E-mail: grault@manguinhos.ensp.fiocruz.br

Received 4 May 1998

Accepted 31 August 1998
}

Interspecific crossbreedings between geographically isolated species were described by Barbosa: B. alexandrina (Cairo, Egypt) and $B$. glabrata (Recife, Pernambuco, Brazil) in 1956; $B$. straminea (Pernambuco, Brazil) and $B$. peregrina (Ecuador); B. tenagophila (São Paulo, Brazil) and B. peregrina (Ecuador) (Barbosa et al. 1958). Formation of fertile hybrid offspring was observed in these crossbreedings. The same author in 1964 commented on the natural hybridization of $B$. glabrata and B. tenagophila, reporting intermediate forms, explained by the proximity of the respective populations. Later on, Barbosa (1973) observed this process of natural hybridization in the Northeast of Brazil, between B. glabrata and $B$. straminea. Breeding sites previously colonized exclusively by $B$. glabrata were replaced by $B$. straminea over the course of three years. During the process of competitive exclusion, mixed forms were found, possibly resulting from interspecific crossbreeding. Such intermediate forms were no longer found during later field studies, showing their inability to persist in nature.

This study's objectives were to observe the possibility of experimental hybridization between host species for Schistosoma mansoni in Brazil and to study the reproductive capacity and subsequent morphological characterization of the hybrid forms.

\section{MATERIALS AND METHODS}

Intra- and interspecific crossbreedings have been performed between albino and pigmented populations in three intermediate host species for 
schistosomiasis mansoni in Brazil (Fig. 1). In crossbreeding experiments, according to Newton (1954), albino individuals produce pigmented offspring when submitted to crossbreeding with pigmented populations.

The first phase of the experiment involved rearing ten specimens from each strain in isolation for approximately one year. This procedure allowed the strains to maintain homozygosis. Approximately 15 days after eclosion, the offspring of these snails were used in the crossbreeding experiments. They were reared by pairs, according to Fig. 1, in cylindrical recipients measuring 7.5 by $8 \mathrm{~cm}$ with a capacity of $250 \mathrm{ml}$ of water, for a period of 30 days. At the end of this period, the albino specimens were separated from the pigmented ones and their offspring were observed for 24 weeks. The following parameters were observed: reproductive parameters-fecundity (number of egg-masses; number of eggs/egg masses; number of eggs/snail) and fertility parameters (production of fertile and sterile eggs; eclosion rate) and phenotypic parameters-pigmentation of eyes, pigmentation of mantle, and internal morphology, observing differential traits.

The number of egg-masses in albino specimens was observed daily, as were other aspects pertaining to fecundity. Egg-masses were separated weekly and observed as to the production of fertile and sterile eggs. Records were also kept during this same period on the number of snails with

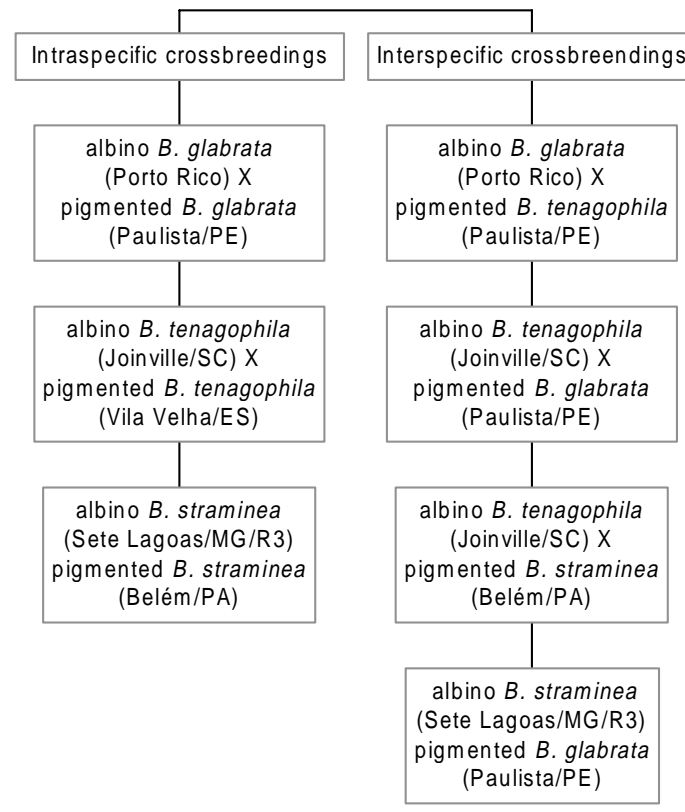

Fig. 1: intra- and interspecific crossbreedings between albino and pigmented host species for schistosomiasis mansoni in Brazil. black and white eyes in each egg-masses. The number of eclosed snails was recorded every six days.

Part of F1, coming from interspecific crossbreedings, was reared in isolation (10 pairs) and grouped (30 specimens) at approximately 15 days of age under the same conditions as in the previous experiment, observing the same parameters in this generation. Another part was submitted to anatomical dissection in order to establish the presence or absence of the renal ridge, using histological cross sections.

\section{RESULTS}

Viable hybrid offspring were only obtained with the interspecific crossbreeding of pigmented $B$. glabrata (Paulista, PE) and albino B. tenagophila (Joinville, SC), with the formation of F1 and F2. Crossbreeding of albino B. straminea (R3) and pigmented B. tenagophila (Vila Velha, ES) was the only one to maintain reproductive isolation. The other crossbreedings produced hybrid offspring, but the specimens died before reaching sexual maturity.

All offspring of the crossbreeding between pigmented B. glabrata (Paulista, PE) and albino $B$. tenagophila (Joinville, SC) had black eyes, pigmented mantles of the spotted "Wildtype" described by Richards (1967), and a renal ridge on the mantle (Figs 2,3), with the latter confirmed by histological cross section (Fig. 4).

Hybrid offspring from generation F2 reared separately had $67.7 \%$ of snails with black eyes and $32.2 \%$ with red eyes, or a ratio of $2: 1$. Snails reared together showed $78.9 \%$ with black eyes and $21 \%$ with red eyes, or a ratio of some 3:1. Comparing the number of snails with red as opposed to black eyes reared separately or grouped showed a significant difference $\left(X^{2}=11.31 ; p>0.05\right)$, with a predominance of black-eyed snails reared in groups.

Table I shows fecundity results and Table II fertility results for ten specimens of albino $B$. tenagophila (Joinville, SC) submitted to intraspecific crossbreeding with pigmented $B$. tenagophila (Vila Velha, ES) and interspecific crossbreeding with pigmented $B$. glabrata (Paulista, PE). Comparing reproductive parameters for albino $B$. tenagophila submitted to intra- and interspecific crossbreeding, no significant difference was observed with regard to fecundity: number of egg masses $(t=0.11, p=0.91$, g.l. $=13)$; number of eggs/egg-masses $(\mathrm{t}=-1.72, \mathrm{p}=0.13$, g.l. $=7)$; number of eggs/snail $(\mathrm{t}=-1.51, \mathrm{p}=0.17$, g.l. $=8)$ and fertility: number of fertile eggs $(\mathrm{t}=-1.69, \mathrm{p}=$ 0.13 , g.l. $=7)$; number of sterile eggs $(\mathrm{t}=0.57, \mathrm{p}=$ 0.59 , g.l. $=5)$, and number of eclosed snails $(\mathrm{t}=-$ $1.66, \mathrm{p}=0.13$, g.l. $=8$ ). 


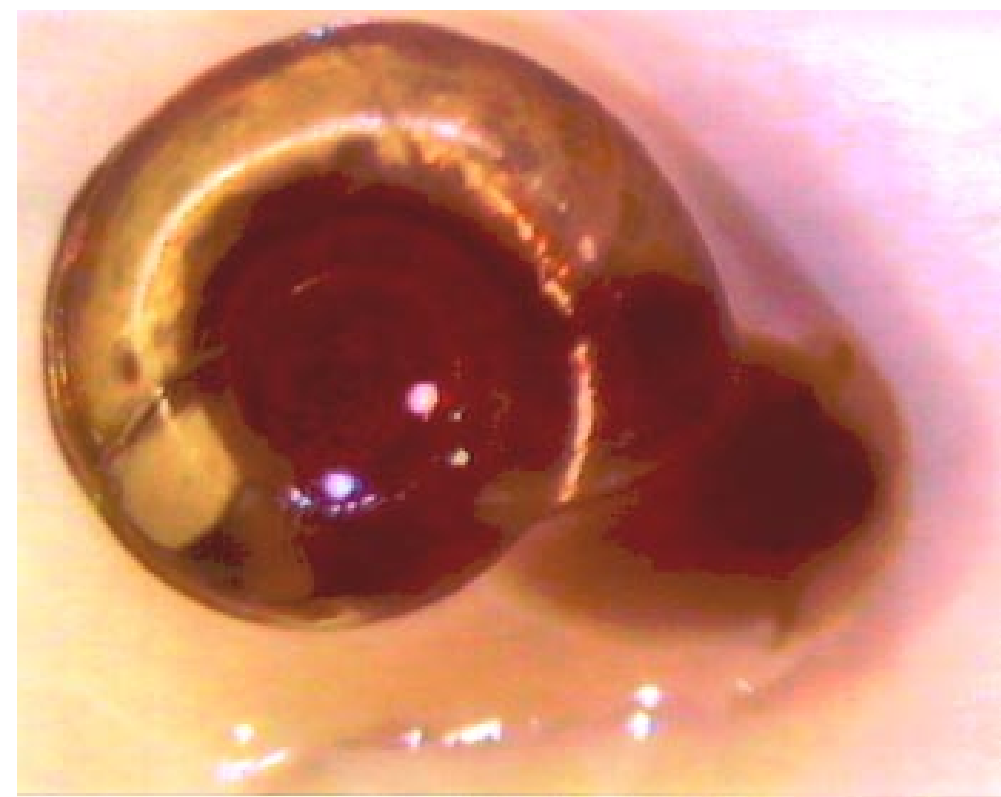

Fig. 2: specimen of generation F1 from crossbreeding of pigmented Biomphalaria glabrata (Paulista, PE) and albino B. tenagophila (Joinville, SC), with black eyes and pigmented mantle of the spotted "Wildtype" (magnified 20X) (size: $5 \mathrm{~mm}$ ).

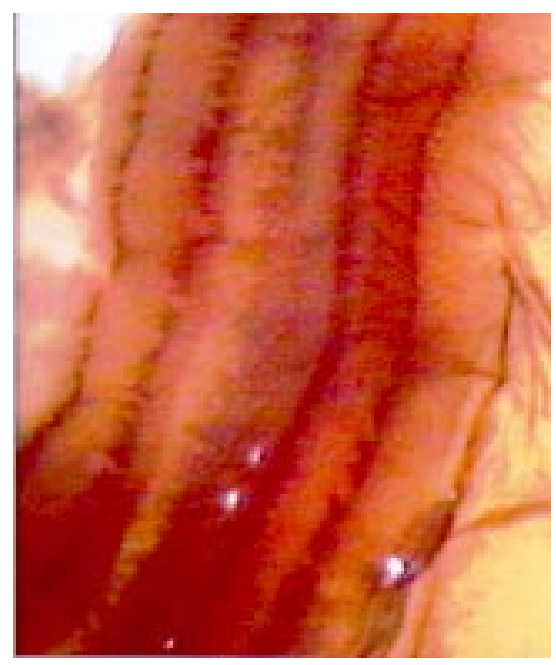

Fig. 3: presence of renal ridge in specimens from generation $\mathrm{F} 1$ of crossbreeding between pigmented Biomphalaria glabrata (Paulista, PE) and albino B. tenagophila (Joinville, SC) (magnified 40X).

Tables III and IV show the fecundity and fertility results for generation $\mathrm{F} 2$ reared in isolation and grouped. A proportional equivalence was observed for values obtained for the number of eggs/ egg-masses at week 7 for the two situations (Table III). In terms of fertility, both in isolation and grouped, production of fertile eggs and eclosion of snails were achieved.

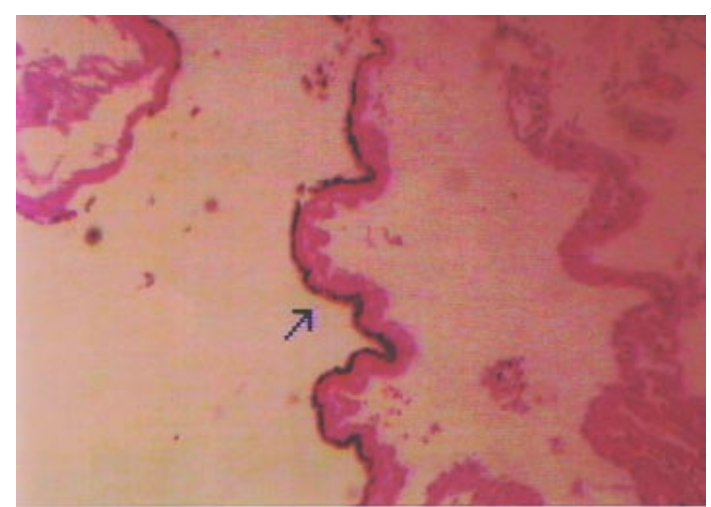

Fig. 4: presence of renal ridge, observed in longitudinal cross section, in specimens from generation $\mathrm{F} 1$ of crossbreeding between pigmented Biomphalaria glabrata (Paulista, PE) and albino B. tenagophila (Joinville, SC) (magnified 40X).

\section{DISCUSSION}

The results of this experiment agree with those of interspecific crossbreedings performed previously by Barbosa using B. alexandrina (Cairo, Egypt) and B. glabrata (Recife, Pernambuco, Brazil) in 1956; $B$. straminea (Pernambuco, Brazil) and $B$. peregrina (Ecuador); and B. tenagophila (São Paulo, Brazil) and B. peregrina (Ecuador) (Barbosa et al. 1958), producing fertile hybrid offspring in all the crossbreedings performed. 
TABLE I

Mean fecundity parameters for ten specimens of albino Biomphalaria tenagophila (Joinville, SC) submitted to intraspecific crossbreeding (with pigmented B. tenagophila - Vila Velha, ES) and interspecific crossbreeding (with pigmented B. glabrata - Paulista, PE)

\begin{tabular}{|c|c|c|c|c|c|c|c|c|c|c|}
\hline \multirow[b]{3}{*}{ Weeks } & \multicolumn{10}{|c|}{ Albino B. tenagophila } \\
\hline & \multicolumn{5}{|c|}{ Intraspecific crossbreeding } & \multicolumn{5}{|c|}{ Interspecific crossbreeding } \\
\hline & $\begin{array}{c}\text { Total } \\
\text { number of } \\
\text { egg-masses }\end{array}$ & $\begin{array}{c}\text { Medium } \\
\text { number of } \\
\text { egg-masses/ } \\
\text { snail }\end{array}$ & $\begin{array}{c}\text { Total } \\
\text { number } \\
\text { of eggs }\end{array}$ & $\begin{array}{l}\text { Medium } \\
\text { number of } \\
\text { eggs/snail }\end{array}$ & $\begin{array}{c}\text { Medium } \\
\text { number } \\
\text { of eggs/ } \\
\text { egg-masses }\end{array}$ & $\begin{array}{c}\text { Total } \\
\text { number of } \\
\text { egg-masses }\end{array}$ & $\begin{array}{c}\text { Medium } \\
\text { number of } \\
\text { egg-masses/ } \\
\text { snail }\end{array}$ & $\begin{array}{c}\text { Total } \\
\text { number } \\
\text { of eggs }\end{array}$ & $\begin{array}{c}\text { Medium } \\
\text { number of } \\
\text { eggs/snail }\end{array}$ & $\begin{array}{c}\text { Medium } \\
\text { number } \\
\text { of eggs/ } \\
\text { egg-masses }\end{array}$ \\
\hline 1 & - & - & - & - & - & - & - & - & - & - \\
\hline 2 & - & - & - & - & - & 9 & 0,9 & 65 & 6,6 & 7,2 \\
\hline 3 & 13 & 1,3 & 37 & 3,7 & 2,8 & 8 & 0,8 & 114 & 11,4 & 14,2 \\
\hline 4 & 13 & 1,3 & 23 & 2,3 & 1,8 & - & - & - & - & - \\
\hline 5 & 17 & 1,7 & 28 & 2,8 & 1,6 & 16 & 1,6 & 126 & 12,6 & 7,9 \\
\hline 6 & - & - & - & - & - & - & - & - & - & - \\
\hline 7 & - & - & - & - & - & - & - & - & - & - \\
\hline 8 & - & - & - & - & - & - & - & - & - & - \\
\hline 9 & - & - & - & - & - & 7 & 0,7 & 22 & 2,2 & 3,1 \\
\hline
\end{tabular}

TABLE II

Mean fertility parameters for ten specimens of albino Biomphalaria tenagophila (Joinville, SC) submitted to intraspecific crossbreeding (pigmented B. tenagophila Vila Velha, ES) and interspecific crossbreeding (pigmented B. glabrata - Paulista, PE)

\begin{tabular}{|c|c|c|c|c|c|c|c|c|c|c|c|c|}
\hline \multicolumn{13}{|c|}{ Albino B. tenagophila } \\
\hline & \multicolumn{6}{|c|}{ Intraspecific crossbreeding } & \multicolumn{6}{|c|}{ Interspecific crossbreeding } \\
\hline Weeks & $\begin{array}{c}\text { Total } \\
\text { number } \\
\text { of eggs/ } \\
\text { snail }\end{array}$ & $\begin{array}{c}\text { Medium } \\
\text { number } \\
\text { of sterile } \\
\text { eggs/snail }\end{array}$ & $\begin{array}{c}\text { Medium } \\
\text { number } \\
\text { of fertile } \\
\text { eggs/snail }\end{array}$ & $\begin{array}{c}\text { Medium } \\
\text { number } \\
\text { of eclosed } \\
\text { snails }\end{array}$ & $\begin{array}{l}\% \text { of } \\
\text { fertile } \\
\text { eggs }\end{array}$ & $\begin{array}{c}\% \text { of } \\
\text { eclosed } \\
\text { snails }\end{array}$ & $\begin{array}{c}\text { Total } \\
\text { number } \\
\text { of eggs/ } \\
\text { snail }\end{array}$ & $\begin{array}{c}\text { Medium } \\
\text { number } \\
\text { of sterile } \\
\text { eggs/snail }\end{array}$ & $\begin{array}{c}\text { Medium } \\
\text { number } \\
\text { of fertile } \\
\text { eggs/snail }\end{array}$ & $\begin{array}{c}\text { Medium } \\
\text { number } \\
\text { of eclosed } \\
\text { snails }\end{array}$ & $\begin{array}{l}\% \text { of } \\
\text { fertile } \\
\text { eggs }\end{array}$ & $\begin{array}{c}\% \text { of } \\
\text { eclosed } \\
\text { snails }\end{array}$ \\
\hline 1 & - & - & - & - & - & - & - & - & - & - & - & - \\
\hline 2 & - & - & - & - & - & - & 65 & 0 & 6,5 & 6,5 & 100 & 100 \\
\hline 3 & 37 & 0,8 & 2,9 & 2,9 & 78,3 & 100 & 114 & 1,4 & 10 & 7,9 & 87,7 & 79 \\
\hline 4 & 23 & 0,1 & 2,2 & 2,2 & 95,6 & 100 & - & - & - & - & - & - \\
\hline 5 & 28 & 1,7 & 1,1 & 1,1 & 39,2 & 100 & 126 & 0 & 12,6 & 10,8 & 100 & 85,7 \\
\hline 6 & - & - & - & - & - & - & - & - & - & - & - & - \\
\hline 7 & - & - & - & - & - & - & - & - & - & - & - & - \\
\hline 8 & - & - & - & - & - & - & - & - & - & - & - & - \\
\hline 9 & - & - & - & - & - & - & 22 & 0 & 2,2 & 2,2 & 100 & 100 \\
\hline
\end{tabular}


TABLE III

Mean fecundity parameters for ten specimens from generation F2 of crossbreeding between albino Biomphalaria tenagophila (Joinville, SC) and pigmented B. glabrata (Paulista, PE) reared in isolation and thirty specimens reared in groups for ten weeks

\begin{tabular}{|c|c|c|c|c|c|c|c|c|c|c|}
\hline \multicolumn{11}{|c|}{ Generation F2 } \\
\hline \multirow[b]{2}{*}{ Weeks } & \multicolumn{5}{|c|}{ Reared in isolation } & \multicolumn{5}{|c|}{ Reared in groups } \\
\hline & $\begin{array}{c}\text { Total } \\
\text { number of } \\
\text { egg-masses }\end{array}$ & $\begin{array}{c}\text { Medium } \\
\text { number of } \\
\text { egg-masses/ } \\
\text { snail }\end{array}$ & $\begin{array}{c}\text { Total } \\
\text { number } \\
\text { of eggs }\end{array}$ & $\begin{array}{c}\text { Medium } \\
\text { number of } \\
\text { eggs/snail }\end{array}$ & $\begin{array}{l}\text { Medium } \\
\text { number } \\
\text { of eggs/ } \\
\text { egg-masses }\end{array}$ & $\begin{array}{c}\text { Total } \\
\text { number of } \\
\begin{array}{c}\text { egg-masses } \\
\text { snail }\end{array} \\
\end{array}$ & $\begin{array}{c}\text { Medium } \\
\text { number of } \\
\text { egg-masses/ }\end{array}$ & $\begin{array}{c}\text { Total } \\
\text { number } \\
\text { of eggs }\end{array}$ & $\begin{array}{l}\text { Medium } \\
\text { number of } \\
\text { eggs/snail }\end{array}$ & $\begin{array}{c}\text { Medium } \\
\text { number } \\
\text { of eggs/ } \\
\text { egg-masses }\end{array}$ \\
\hline 1 & - & - & - & - & - & - & - & - & - & - \\
\hline 2 & - & - & - & - & - & - & & - & - & - \\
\hline 3 & 8 & 0,8 & 54 & 5,4 & 6,75 & - & - & - & - & - \\
\hline 4 & 24 & 2,4 & 350 & 35 & 14,6 & - & - & - & - & - \\
\hline 5 & - & - & - & - & - & - & - & - & - & - \\
\hline 6 & - & - & - & - & - & - & - & - & - & - \\
\hline 7 & 20 & 2 & 116 & 11,6 & 5,8 & 10 & 0,3 & 58 & 1,9 & 5,8 \\
\hline 8 & - & - & - & - & - & - & - & - & - & - \\
\hline 9 & - & - & - & - & - & - & - & - & - & - \\
\hline 10 & - & - & - & - & - & - & - & - & - & - \\
\hline
\end{tabular}

TABLE IV

Mean fertility parameters for ten specimens from generation F2 of crossbreeding between albino Biomphalaria tenagophila (Joinville, SC) and pigmented B. glabrata (Paulista, PE) reared in isolation and thirty specimens reared in groups for ten weeks

\begin{tabular}{|c|c|c|c|c|c|c|c|c|c|c|c|c|}
\hline \multicolumn{13}{|c|}{ Generation F2 } \\
\hline \multirow[b]{2}{*}{ Weeks } & \multicolumn{6}{|c|}{ Reared in isolation } & \multicolumn{6}{|c|}{ Reared in groups } \\
\hline & $\begin{array}{l}\text { Total } \\
\text { number } \\
\text { of eggs/ } \\
\text { snail }\end{array}$ & $\begin{array}{c}\text { Medium } \\
\text { number } \\
\text { of sterile } \\
\text { eggs/snail }\end{array}$ & $\begin{array}{l}\text { Medium } \\
\text { number } \\
\text { of fertile } \\
\text { eggs/snail }\end{array}$ & $\begin{array}{l}\text { Medium } \\
\text { number } \\
\text { of eclosed } \\
\text { snails }\end{array}$ & $\begin{array}{l}\% \text { of } \\
\text { fertile } \\
\text { eggs }\end{array}$ & $\begin{array}{c}\% \text { of } \\
\text { eclosed } \\
\text { snails }\end{array}$ & $\begin{array}{l}\text { Total } \\
\text { number } \\
\text { of eggs/ } \\
\text { snail }\end{array}$ & $\begin{array}{l}\text { Medium } \\
\text { number } \\
\text { of sterile } \\
\text { eggs/snail }\end{array}$ & $\begin{array}{c}\text { Medium } \\
\text { number } \\
\text { of fertile } \\
\text { eggs/snail }\end{array}$ & $\begin{array}{l}\text { Medium } \\
\text { number } \\
\text { of eclosed } \\
\text { snails }\end{array}$ & $\begin{array}{l}\% \text { of } \\
\text { fertile } \\
\text { eggs }\end{array}$ & $\begin{array}{c}\% \text { of } \\
\text { eclosed } \\
\text { snails }\end{array}$ \\
\hline 1 & - & - & - & - & - & - & - & - & - & - & - & - \\
\hline 2 & - & - & - & - & - & - & - & - & - & - & - & - \\
\hline 3 & 54 & 0 & 5,4 & 5,4 & 100 & 100 & - & - & - & - & - & - \\
\hline 4 & 350 & 0 & 35 & 35 & 100 & 100 & - & - & - & - & - & - \\
\hline 5 & - & - & - & - & - & 100 & - & - & - & - & - & - \\
\hline 6 & - & - & - & - & - & - & - & - & - & - & - & \\
\hline 7 & 116 & 0 & 11,6 & 11,6 & 100 & - & 58 & 0 & 5,8 & 5,8 & 100 & 100 \\
\hline 8 & - & - & - & - & - & - & - & - & - & - & - & - \\
\hline 9 & - & - & - & - & - & - & - & - & - & - & - & - \\
\hline 10 & - & - & - & - & - & - & - & - & - & - & - & - \\
\hline
\end{tabular}


As for morphological traits, generation F1 of the crossbreeding between albino B. tenagophila (Joinville, SC) and pigmented B. glabrata (Paulista, $\mathrm{PE})$ displayed black eyes with the presence of a renal ridge, phenotypic traits observed in the pigmented parental specimen, while these traits were dissociated in generation F2. These results were similar to those found by Barbosa (1956) in the crossbreeding between $B$. alexandrina (Cairo, Egypt) and $B$. glabrata (Recife, Pernambuco, Brazil).

Another trait observed in the offspring of the albino specimen was the pigmented mantle. All offspring of both intraspecific and interspecific crossbreedings were individuals characterized as the spotted "Wildtype" (Richards 1967). This phenotype was similar to that found by Richards (1969), where crossbreedings of "albino" individuals with those of the diffuse "Wildtype" led to the formation of "Wildtype" individuals with the dominant spotted pattern.

As for the histology of the mantle, hybrid offspring from interspecific crossbreeding between albino B. tenagophila (Joinville, SC) and pigmented B. glabrata (Paulista, PE) had the renal ridge, a trait of $B$. glabrata. This trait had been observed previously in nature by Barbosa (1957), who found specimens of B. tenagophila (São Gonçalo, RJ) with the renal ridge and/or a pigmented line on the mantle. The author suggested that the breeding site was a transition zone with the presence of intermediate forms resulting from a possible crossbreeding with $B$. glabrata, although this species was not found nearby. In addition, previous research suggests that certain species are natural hybrids that became efficient. WiumAndersen (1973) suggests that B. alexandrina is a hybrid of $B$. pfeiferi and B. sudanica, while Simões et al. (1985) suggests that $B$. intermedia is a hybrid of B. straminea and B. peregrina.

In the current study, both the phenotypic and genotypic traits of hybrids may be diluted through gene exchanges. The fecundity and fertility results in the fertile hybrid offspring show that generation F2 was not as efficient as generation F1. Such results can be explained by the allopatric speciation theory, involving the formation of a normal, vigorous, and fertile hybrid F1 generation, but a weak F2 generation with the presence of sterile individuals (Krebs 1985).
This study showed that the interspecific crossbreeding of albino B. tenagophila (Joinville, SC) and pigmented B. glabrata (Paulista, PE) was feasible, with the formation of fertile hybrid offspring. The phenotypes displayed by generation F1 and F2 indicated the existence of simple Mendelian inheritance for these traits in the planorbid populations. With regard to reproductive aspects, the fecundity and fertility of the generations decreased, tending to form sterile individuals, thus suggesting post-zygotic reproductive isolation.

\section{REFERENCES}

Barbosa FS 1956. Cross-breeding of Australorbis glabratus and Biomphalaria boissyi. Trans $R$ Soc Trop Med Hyg 50: 296-297.

Barbosa FS 1964. The renal ridge a disputed feature of anatomy of planorbid snail Australorbis tenagophilus. Rev Inst Med Trop São Paulo 6: 64-70.

Barbosa FS 1973. Possible competitive displacement and evidence of hybridization between two Brazilian species of planorbid snails. Malacologia 14: 401408.

Barbosa FS, Coelho MV 1957. Notes on anatomy of two Brazilian planorbid snails. Rev Bras de Biol 1: 113-115.

Barbosa FS, Barbosa I, Carneiro E 1958. The anatomy of Tropicorbis philippianus (Dunker) and its relationships to the Brazilian planorbidae (Molusca, Pulmonata). J Conchyliologie 93: 180-184.

Krebs CJ 1985. Ecology, Harper Internacional, New York, $800 \mathrm{pp}$.

Newton WL 1954. Albinism in Australorbis glabratus. Proc Helminth Soc Wash 21: 72-74.

Paraense WL 1955. Self and cross-fertilization in Australorbis glabratus. Mem Inst Oswaldo Cruz 53: 285-291.

Paraense WL, Deslandes N 1955. Isolamento reprodutivo entre Australorbis glabratus e A. nigricans. Mem Inst Oswaldo Cruz 53: 321-324.

Richards CS 1967. Genetic studies on Biomphalaria glabrata (Basommatophora: Planorbidae), a third pigmentation allele. Malacologia 5: 335-340.

Richards CS 1969. Genetic studies on Biomphalaria glabrata: mantle pigmentation. Malacologia 9: 339348.

Simões LCG, Kawano T, Hofmann PRP 1985. Citogenética do gênero Biomphalaria. Ciênc Cult 37: 1289-1293.

Wium-Andersen G 1973. Electrophoresis as a support for the identification of various African Biomphalaria. Malacologia 14: 287-289. 